\title{
What Is Spontaneous Order?
}

Daniel Luban, University of Oxford (daniel.luban@univ.ox.ac.uk)

This is the manuscript version of an article that was published in the American Political Science Review. The version of record can be found here: https://doi.org/10.1017/S0003055419000625

ABSTRACT: Due especially to the work of Friedrich Hayek, "spontaneous order" has become an influential concept in social theory. It seeks to explain how human practices and institutions emerge as unintended consequences of myriad individual actions, and points to the limits of rationalism and conscious design in social life. The political implications of spontaneous order theory explain both the enthusiasm and the skepticism it has elicited, but its basic mechanisms remain elusive and underexamined. This article teases out the internal logic of the concept, arguing that it can be taken to mean several different things. Some are forward-looking (defining it in terms of present-day functioning), whereas others are backward-looking (defining it in terms of historical origins). Yet none of these possibilities prove fully coherent or satisfactory, suggesting that spontaneous order cannot bear the analytical weight that has been placed on it.

\section{Spontaneity}

"[W]hy did he without need bring in this strange word, spontaneous?" So lamented Thomas Hobbes $(1841,91)$, in the midst of his debate with Bishop Bramhall on free will. The term, originating in scholastic philosophy, was in Hobbes's eyes too ambiguous to be useful; it was never quite clear which forms of action it was meant to label, allowing Bramhall to "give it any signification he please" without regard for consistency. More than that, Hobbes was irked by his opponent weighing down their debate with a piece of Latin jargon - "for English," he grumbled, "it is not" $(1841,350-51)$. On that last point, at least, Hobbes would end up being wrong, although not for reasons he could have anticipated: today, the $O E D$ lists his 1656 text as its first recorded instance of "spontaneous" in English. Aiming to keep the word out of the language, he had unwittingly helped usher it in.

The irony suits the theme. As "spontaneous order" has become a key concept in modern social theory, it is precisely the gap between intentions and consequences that has served as its central motif. Theorists of spontaneous order emphasize that human society rests on practices and institutions that are the unintended consequences of myriad individual actions. They argue that social order is - or can be, or should be- "grown" rather than "made," the result of gradual evolution rather than conscious planning. Such theories offer grounds for optimism, suggesting that human short-sightedness and self-seeking might constitute a blessing rather than a curse. But 
they also carry a note of warning: grown order is a fragile thing, liable to be destroyed by the overambitious efforts of planners and reformers.

It's common to trace the roots of spontaneous order theories to the Scottish Enlightenment. David Hume described how conventions can arise tacitly, without any explicit agreement between the parties involved $(1978,490)$. Adam Ferguson suggested that "nations stumble upon establishments, which are indeed the result of human action, but not the execution of any human design" $(1995,119)$. And Adam Smith's account of how market participants are "led by an invisible hand to promote an end which was no part of [their] intention" became the canonical example for later theorists of spontaneous order (1976a, 456).

Whether or not we take the Scots to be offering an account of spontaneous order in the modern sense- - I will argue that they were not - the concept only came to be theorized explicitly in the twentieth century. The term itself was coined by Michael Polanyi $(1941,1951) .{ }^{1}$ But it owes its current prominence chiefly to the work of Friedrich Hayek, who put the concept at the center of his work beginning in the 1960s (see especially 1973, 1976, 1979). Polanyi and Hayek were staunch anti-communists, and the Cold War context is crucial for understanding why they found spontaneous order an appealing idea. In many ways Hayek's invocation of it can be read as an extension of the arguments he had been making against central planning since the 1930s (collected in Hayek 1948). And doubtless he saw the market as the archetypal form of spontaneous order, one threatened by the encroaching forces of what he called "constructivist rationalism."

But to reduce the theory to a simple defense of the market would be to understate its explanatory ambitions. It aims to explain not just money and markets, but language and law; in Hayek's hands, it would be wedded to an account of the evolution of human practices and institutions in general. ${ }^{2}$ Nor does spontaneous order theory restrict itself to the human realm. On the

\footnotetext{
${ }^{1}$ At least in English, although August Comte had used the term ordre spontané a century earlier. This usage seems not to have influenced the twentieth-century spontaneous order theorists, and Hayek in particular was deeply hostile to Comte (cf. Bourdeau 2016).

2 Although often inspired by economic processes, spontaneous order is thus a piece of social theory rather than economics. (Hayek's own focus on it coincided with his turn away from mainstream economics, on which see Caldwell 2004). Our verdict on the concept therefore need not entail any sweeping economic conclusions in itself. To deny that markets are best understood as spontaneous orders, for instance, would not itself imply anything about their overall desirability (except insofar as it deprives them of one particular rhetorical justification).
} 
contrary, one of its most attractive features is its purported continuity with the natural sciences, as human societies come to be revealed as a subset of the broader phenomenon of "emergent order," examples of which can be found on scales ranging from the microscopic to the cosmic. Indeed, this apparent homology between the human and non-human worlds has been central to thinking about self-organizing systems since at least the eighteenth century (Sheehan and Wahrman 2015).

The concept is broader than it might seem, and more ubiquitous. It's easy to argue that this or that social institution is not a genuinely spontaneous product, harder to break free of the notion of spontaneity altogether. Consider, for instance, the famous attack on the illusions of market fundamentalism by Karl Polanyi (Michael's brother, though with decidedly different politics). Polanyi argued that unfettered markets did not emerge naturally but were consciously imposed upon unwilling populaces: "Laissez-faire was planned, planning was not" $(2001,147)$. Thus he denied spontaneity to markets and laissez-faire-only to attribute it in turn to his own favored set of social processes: "The countermove against economic liberalism and laissez-faire possessed all the unmistakable characteristics of a spontaneous reaction" $(2001,156) .{ }^{3}$ A striking but not atypical example. For spontaneity (like the related notion of "nature") has a way of remaining in the background even when explicitly disavowed, and many of those hostile to Hayek's particular political program still hold onto some vision of what a genuinely spontaneous order would look like.

For that reason, my aim here is to examine spontaneous order on a more basic level: not so much to critique its empirical accuracy or its political implications in particular cases, but to ask what it could mean and how it might work in general. I do so with particular reference to Hayek, who is the most famous and systematic spontaneous order theorist, but with the hope of arriving at conclusions applicable to other versions of the theory. ${ }^{4}$

\footnotetext{
3 On the parallels between Karl Polanyi and Hayek, see Luban 2017, Dale 2018, Mirowski 2018.

${ }^{4}$ Kley 1994 offers an especially sharp critique of Hayek's particular account, but most of the major treatments of his thought have relevant things to say about the subject (see, among others, Gray 1984, Kukathas 1989, Gamble 1996, Petsoulas 2001, Caldwell 2004). Useful recent critiques include Sandefur 2009, Dale 2018, Whyte 2019. All of these treatments tend to focus on what I will call the "backward-looking" side of the theory more than the "forward-looking" side.
} 
The most immediate conclusion is negative: there is no single unambiguous notion of spontaneous order, but rather a range of overlapping notions, none of which proves entirely satisfactory for the theory's purposes. This might suggest that we would do well to abandon the theory altogether. Yet at the same time its failures are instructive, for they point to deeper ambiguities in basic concepts that are central to the theory, but far from exclusive to it. The intuitive notion of an order that arises in the absence of outside interference can mean dramatically different things depending on how we understand "order," "interference," and even "outside." Likewise, the seemingly-straightforward doctrine of unintended consequences takes on very different political valences when stripped of the tacit premises that spontaneous order theory builds into it.

The argument proceeds as follows. I begin by considering several conceptions we might describe as "forward-looking," in which spontaneous order is characterized by certain formal features that don't depend on any particular historical origin story. Spontaneous order might refer to any set of unintended social regularities at all, or to a system lacking formal hierarchy, or to a framework of abstract and general rules that are themselves intentionally designed. Yet each of these conceptions has its problems: the first doesn't sufficiently differentiate order from disorder; the second risks becoming a bare legalism rather than a social theory; the third elides the supposedly fundamental distinction between conscious construction and spontaneous growth.

These difficulties help explain why spontaneous order theories tend to have a "backwardlooking" side, defining such an order not just in terms of its current functioning but in terms of how it came into being. Hayek's theory of cultural evolution is the most important backwardlooking account. But at the same time reveals the pitfalls of the enterprise, for Hayek's story of the "evolution of individual freedom" must rely on a stylized and implausible view of the actors who participate in this history. This problem, I suggest, is not accidental, for any backward-looking account must isolate some human capacities that it deems suitably "spontaneous" and try to show that its favored institutions arose through the exclusive exercise of these capacities. Is it possible to abandon these implausible features of spontaneous order theory while preserving some of its insights, most notably its emphasis on the undesigned and unpredictable nature of the historical process? I close by tracing such an impulse in the thinkers of the Scottish Enlightenment, whose work presupposed a very different understanding of unintended consequences, and 
of the relationship of politics and economics, than that of their successors. Often held up as pioneers of spontaneous order theory, they might better be understood as critics avant la lettre.

\section{Order}

"Order" is an ambiguous term. It can refer to any system exhibiting regularities of any kind; alternately, it can be restricted to only those systems exhibiting certain normatively desirable regularities. A social order, for instance, might either be defined by the mere existence of "predictable patterns of behavior," or more strongly by the prevalence of "cooperative behavior" (Elster 1989, 1)..$^{5}$ Others draw a different distinction between "normative order" and "factual order" that depends on how order is produced: whether by subjective consensus, or by unintended consequences occurring behind the backs of actors themselves (Parsons 1968, I: 91-92).

In terms of this second distinction, spontaneous order looks like a form of factual rather than normative order. It aims to explain how regularities come about without recourse to any single conscious plan, whether the decision of an individual or the explicit consensus of a group. Indeed, the test of whether any particular "invisible-hand explanation" is compelling is whether it can do so successfully (Ullmann-Margalit 1978).

What about the first distinction? Must a spontaneous order be a normatively desirable one? Hayek wants to say no. He defines order as any "state of affairs in which a multiplicity of elements of various kinds are so related to each other that we may learn from our acquaintance with some...part of the whole to form correct expectations concerning the rest" $(1973,36$, original emphasis). More simply, order is defined by predictability rather than desirability. And this definition follows from the fact that Hayek, like other spontaneous order theorists, takes the concept to encompass non-human as well as human orders. When examining the structure of a chemical compound, or the pattern formed by iron filings under a magnet, to take two of his examples $(1973,38-39)$, it would seem to be a category error to ask whether they should behave as

\footnotetext{
5 Order is sometimes considered an inherently conservative concept (think "law and order"), but both of these definitions are politically open-ended. An anarchist society, for instance, might unproblematically be understood as a social order insofar as its members reliably engage in some practices (like mutual aid) while avoiding others (like aggression).
} 
they do, whether it's good that they do so. Indeed, part of the underlying political aim of Hayek's formulation is to sidestep debates about the normative desirability of markets, and to focus instead on their factual orderliness. Hence his complaint about those who describe economic life under capitalism as "chaotic," due to their failure to perceive "the order which exists and the manner in which it is formed" $(1964,3)$.

But elsewhere Hayek suggests that "not every regularity in the behavior of the elements does secure an overall order," for some regularities of conduct "could only produce disorder." If every individual were to attack or flee from every other, for instance, the result would be "the complete impossibility of an order in which the activities of the individuals were based on collaboration with others" $(1973,44)$. Note the slippage here between "overall order" as such and “order based on collaboration with others"; Hayek's thought seems to be that some level of social harmony is necessary for any kind of order to arise. However minimal a notion order might be, it doesn't extend to a Hobbesian war of all against all.

Yet just as Hayek accuses his opponents of failing to perceive the order that underlies the seeming chaos of economic life, a similar charge might be leveled against him in turn, for orderly regularities can be found in even the most extreme cases of social disharmony. The basic thought is an old one. There can be "no war without some degree of peace," Augustine wrote in the City of God $(1998,939)$, for even a battle that descends into anarchy continues to manifest certain traces of the order that is evident (at least to a properly-minded observer) in every aspect of God's creation. In the wake of the French Revolution, Joseph de Maistre would put the point more polemically. Against those who saw only chaos in the revolution's dizzying reversals, de Maistre insisted that "never is order more visible, never is Providence more palpable" $(1974,26)$. Surveying instances of "the violent destruction of the human species" throughout history, he held out the possibility of one day apprehending their lawful character: "If one had a table of massacres similar to a meteorological table, who knows whether, after centuries of observation, some law might not be discovered?" $(1974,58)$.

Such statements might strike us as nothing but outdated providentialism, no longer relevant in a disenchanted world. Yet present-day students of politics should appreciate their pertinence, for many of our own investigations share de Maistre's willingness to “admire order in 
disorder" $(1974,37)$. There are patterns to be apprehended (if not necessarily predicted in advance) in a riot, a civil war, or a revolution, and hypotheses about the shape of such patterns are often quite elegant in their orderliness (e.g. Kalyvas 2006). Some of these patterns might be short-lived and unstable; others can be endemic and long-lasting. ${ }^{6}$ And all of them have a strong claim to spontaneity, insofar as they are the unintended consequences of the interactions of myriad actors with different—and often opposing — goals.

Here we arrive at one possible endpoint for a theory of spontaneous order. The minimal, value-neutral concept of order proves far broader than intended, expanding to include precisely those cases of disorder that it was supposed to exclude. The doctrine of unintended consequences becomes something like a universal axiom: any set of human actions, from everyday exchange to revolutionary upheaval, will have consequences that go beyond what the actors intended, and these consequences will form patterns that might (from the proper perspective) appear orderly. Of course, we might continue to distinguish between desirable and undesirable spontaneous orders - the order arising from market competition is good, the order arising from endemic warfare is bad-but the social-theoretic concept of order has ceased to do any work in such judgments, which must instead stem from our own normative commitments. If we approve of the pattern produced by market competition, for instance, this will be due to whatever specific features we like about it rather than anything about its distinctive status as a spontaneous order.

If the theory of spontaneous order can't rest on this minimal notion of predictable and unintended regularities, what could it rest on? Answering this question requires us first to examine more closely the notion of "unintended consequences," which proves to be less straightforward than it initially appears (cf. Merton 1936, Vernon 1979). In its most basic form, as just noted, the doctrine of unintended consequences might be considered almost axiomatic: there is always a gap between intentions and consequences, and collective outcomes will never correspond precisely to the designs of any individual actor. But when spontaneous order theorists invoke the idea, they typically have two stronger implications in mind. Let's call them fecundity and perversity.

\footnotetext{
6 Some economists have extended the concept of equilibrium beyond the familiar case of market exchange, arguing that a world governed by force and coercion can generate its own "equilibrium" manifesting many of the same formal features (Piccione and Rubinstein 2007).
} 
Fecundity is the optimistic side of the doctrine of unintended consequences. It holds that self-interested and short-sighted individual actions can be better than they think, exceeding the actors' intentions in beneficent ways. The canonical statement comes from the passage in the Wealth of Nations where Adam Smith lays out the logic of the "invisible hand": "By pursuing his own interest, he frequently promotes that of the society more effectually than when he really intends to promote it" (1976a, 456). Perversity is the pessimistic side of the doctrine. It holds that ambitious efforts at social improvement will generate malign consequences, and founder upon the recalcitrance of individuals (cf. Hirschman 1991). Here again the canonical formulation comes from Smith, this time in his discussion of the "man of system" who thinks he can arrange the members of society like pieces on a chessboard, not understanding that "in the great chessboard of human society, every single piece has a principle of motion of its own" (1976b, 233-34). Taken together, the two notions constitute a kind of critique of pride and ode to humility: those who aim to remake the world will make it worse, while those who renounce such ambitions will make it better. ${ }^{7}$ Theories of spontaneous order combine these optimistic and pessimistic strands, these simultaneous notes of hope and warning. In doing so they go beyond the bare doctrine of unintended consequences, whose only implication is the sheer unpredictability of human affairs, and stake a stronger claim to some form of predictability.

We begin to see how misleading the apparent homology between natural and social orders proves to be. As noted, normative language seems inappropriate when applied to non-human orders; we don't say that any individual iron filing under a magnet should behave other than the way in which it does. ${ }^{8}$ Likewise, the dichotomy between spontaneously "grown" and consciously "made" orders is largely inapplicable to the non-human world, where all order (with occasional exceptions like a bird's nest or a beaver's dam) appears to be grown rather than made. ${ }^{9}$ But in the case of spontaneous social order, it seems that we can do wrong - that unlike iron filings, human

\footnotetext{
${ }^{7}$ Hayek suggests that constructivist rationalism owe its political success to its "great appeal to human pride and ambition," and notes by contrast how "[h]umiliating to human pride" his own view might seem $(1960,56,29)$.

8 We might say that the filings "must" obey the laws of physics. But here again it's necessary to disaggregate concepts like "law" and "rule" that seem to play a central role in both natural and social orders, for the sense in which I must obey the criminal law is very different from the sense in which I must obey the laws of physics.

9 Unless, of course, we consider order in nature to be the product of conscious divine creation. But here too, the dichotomy fades away, for by this logic all "grown" order proves to be ultimately "made."
} 
beings are capable of acting in ways that are inconsistent with the requirements of order. It similarly seems that human social order is capable of being made as well as grown (however unsatisfactory the results of such making might be), and this raises the question of how we can distinguish conscious interference from spontaneous growth in practice. What forms of social action, or what sorts of social actor, should be regarded as "exogenous" rather than “endogenous" (Hayek 1973, 37), as coming from outside the grown order rather than inside of it? Which kinds of activity are sufficiently humble to produce fecundity, and which are sufficiently prideful to result in perversity?

More broadly, the minimal and value-neutral conception of order as regularity proves too general to do the work that the theory demands of it. The challenge is to provide a more constrained account of spontaneous order that distinguishes it from other kinds of unintended patterns without collapsing into a purely normative theory. A market, a riot, and a gulag will all exhibit regularities that don't correspond completely to the intentions of any individual actor within them. ${ }^{10}$ So what makes the market distinct, beyond the fact that we might find it more appealing?

\section{Hierarchy}

The simplest criterion by which theorists of spontaneous order have distinguished it from other kinds of order is the absence of formal hierarchy. Michael Polanyi, for instance, defines it as order in which individuals "interact with each other on their own initiative"; though subject to "laws which uniformly apply to all of them," their actions "are not determined by any specific command, whether of a superior or a public authority" (1951, 159, original emphasis). Hayek likewise contrasts the logic of spontaneous order to the logic of "command and obedience" governing the internal structure of an organization. A system in which one central authority issues commands to the subordinate elements is an organization, for which Hayek also uses the Greek term taxis; a system lacking such a commanding authority is a spontaneous order, or kosmos $(1973,36-37)$.

\footnotetext{
10 On the ways in which even a quintessentially top-down and "constructed" order — in this case, a POW camp — still exhibits unintended orderly regularities, see Radford 1945.
} 
So far, so clear. Yet some ambiguities remain. For one thing, this definition might lead us to envision spontaneous order on the model of interstate relations, which are often held to be anarchic (in the technical sense) due to the lack of an international sovereign. A market order, however, is not fully anarchic: its transactions are typically governed by the laws of at least one sovereign state, and to that extent it is indeed subject to formal hierarchy. Here the spontaneous order theorists have a ready answer, one indicated by Polanyi's reference to "laws which uniformly apply" to every individual. The only kind of hierarchy inconsistent with grown order, they hold, is one based on specific commands. General laws, by contrast, provide a background framework within which individuals can make their own free decisions, and to that extent - note here the return of the natural/social homology — "the laws of the state have the same significance for me as the laws of nature" (Hayek 1960, 142). This is the view underlying Hayek's magnum opus The Constitution of Liberty, whose "chief concern" he summarized as "the contention that when we obey laws, in the sense of general abstract rules laid down irrespective of their application to us, we are not subject to another man's will and are therefore free" $(1960,153)$.

We'll return momentarily to some of the difficulties of this view. One initial caveat is that the distinction between taxis (based on commands) and kosmos (based on rules) isn't airtight. Hayek recognizes that any complex organization "must largely rely on rules rather than specific commands" for its governance, and that "these rules of an organization look very much like the general rules underlying a spontaneous order." What distinguishes the largest and most complex organizations from "the order of the whole of society," is, first, that the former still serve particular purposes, whereas the latter is ostensibly purposeless; we can't say that society as a whole aims at any specific goal in the way that an organization does. Second, "this overall order relies entirely on rules... with not even its skeleton determined by commands," and even these "rules which made the growth of this complex order possible were not designed in anticipation of that result," but rather arose spontaneously themselves (1964, 9-10). Here, characteristically for Hayek, we see a claim about the structure of the overall order (that it's based entirely on general rules) entangled with a claim about its origins (that its rules weren't designed for a deliberate purpose). 
The logics of taxis and kosmos are nesting rather than mutually exclusive: the "order of the whole of society" will contain myriad organizations, but will not itself operate as an organization (and likewise, the internal governance of an organization will contain elements of rulegoverned spontaneity as well as elements of hierarchical command). Yet this raises further complications, particularly for how we think about economic life. The rhetoric of the spontaneous order theorists emphasizes the decentralized and non-hierarchical nature of markets. We've seen Michael Polanyi define spontaneous order in terms of individuals acting "on their own initiative," and Hayek describing freedom as a lack of subjection "to another man's will." The basic unit of modern economic life, however, is not the individual but the firm; most workers are subordinates within an organization rather than independent producers. The question is what this (or any similar set of facts about social structure) implies for the overall spontaneity of the economic order. So long as there's no central planner running the economy according to specific commands, does it matter whether a society consists of an array of independent artisans, or a handful of massive bureaucratized firms? Does spontaneity depend simply on the lack of a formal hierarch at the top, or on the substantive structure of the society below?

Spontaneous order theorists typically emphasize the formal criterion over the substantive one. But they are hardly unequivocal, ${ }^{11}$ for understandable reasons - since taking this path risks inserting a legalism into what is meant to be a social theory. The benefits of spontaneous order are supposed to flow from individuals' practical capacity to make use of their knowledge and act on their own initiative, a capacity that depends on the substantive conditions in which they find themselves and not simply on the lack of a central planner. A viable theory of spontaneous order can therefore not afford to be indifferent to social facts and social structure.

Here we touch on deeper problems concerning freedom and coercion. Pure decentralized equality and pure top-down hierarchy are ideal types, and there's no self-evident reason why the state should be the only agency that can exercise "interference" in the requisite sense. In practice, the individual members of a social order are stratified according to a whole range of inequalities, power asymmetries, and social roles, and their capacity to act can be curtailed by more powerful

\footnotetext{
11 See, for instance, Hayek's striking suggestion that the "general in charge of an army or the director of a large construction project" may in important ways be "less free...than the poorest farmer or shepherd" $(1960,17)$.
} 
individuals (bosses, patrons, patriarchs) who are nonetheless their equals in formal legal terms. What counts as spontaneity therefore depends on what counts as interference, as coercion, and Hayek struggled without great success to delimit coercion in the way that his theory required. It would take us too far afield to pursue these issues here. ${ }^{12}$ For present purposes let's simply conclude that we can't base a theory of spontaneous order solely on the absence of a formal economic sovereign.

\section{Rules}

This dissatisfaction with merely formal or legalistic theories of free markets was a central feature of the twentieth-century German school known as ordoliberalism. The ordoliberals emphasized that formal economic freedom was insufficient as a basis for well-functioning markets. Without the proper social framework in place, unfettered markets were likely to result in monopoly and rent-seeking; competition was something that must be actively fostered rather than passively protected.

Hayek was, if not a proper ordoliberal, at least a fellow-traveller. And emphasizing the active construction of markets suggests another possible understanding of spontaneous order. Hayek's account, as noted earlier, often combines "forward-looking" and "backward-looking" claims. On the one hand, we might define spontaneous order as a system that functions in a certain way, regardless of how this system came into being. On the other hand, we might define it in terms of a certain set of origins, a claim that the system arose without conscious design. Hayek is prone to run these strands together, as when he describes Bernard Mandeville's insight that social order sprang from individual strivings "channeled to serve such ends by institutions, practices, and rules which also had never been deliberately invented but had grown up by the survival of what proved successful" (1978, 253, my emphasis). But do the two claims necessarily require one another? If these "institutions, practices, and rules" serve at present to channel individual strivings into a functioning order, does it matter whether they were deliberately invented themselves? Why not simply define spontaneous order in terms of its current operation without requiring that its parts arise spontaneously themselves?

12 I have examined them in greater depth elsewhere (Luban 2018). 
Ordoliberals like Franz Böhm were sympathetic to Hayek’s vision of economic order, but parted ways with him on the question of how it could be implemented; they emphasized that such an order would not arise of its own accord, but required an active moment of sovereign decision to create it (Slobodian 2018, 210-14). While Hayek is less clear on these matters, he does sometimes accept the possibility that spontaneous order might be deliberately created. At one point he suggests that "while the rules on which a spontaneous order rests, may also be of spontaneous origin, this need not always be the case," so that "it is possible that an order which would still have to be described as spontaneous rests on rules which are entirely the result of deliberate design." Similarly, individuals might follow some of the rules necessary to produce order out of their own desires and inclinations, but "there will be still others which they may have to be made to obey," so that spontaneous order may require the active use of state coercive power $(1973,45$ 46).

This line of thought was put into particular focus by Michel Foucault, whose influential 1979 lectures on neoliberalism stressed the activist and interventionist strain in Hayek and the ordoliberals. Foucault saw their work as marking a break from the laissez-faire tendencies of eighteenth- and nineteenth-century liberalism, and an acknowledgement that market competition "can only appear...if it is produced by an active governmentality" $(2008,121)$. He likewise took these thinkers to abandon earlier preoccupations with the "natural" character of economic order. Neoliberalism, Foucault insisted, put no stock in nature, in laissez-faire, or in the notion that market order would arise spontaneously. In large part due to his influence, contemporary scholars often depict neoliberalism as an explicitly interventionist, regulatory, and statist project.

Such contrasts between neoliberalism and an earlier "laissez-faire" can be misleading insofar as they cast the latter as purely anti-statist.13 Whatever we take laissez-faire to have meant historically, it did not typically mean anarcho-capitalism (a niche taste, then and now); the term originated, after all, with the Physiocrats, who saw laissez-faire as entirely consistent with their advocacy of a "legal despotism" in the political realm. If the neoliberal vision involves "a free economy and a strong state" (in Alexander Rüstow's 1932 formulation), this doesn’t in itself

\footnotetext{
13 For a similar argument, see Stahl 2019.
} 
mark it as radically new. ${ }^{14}$ Likewise, while Hayek and the ordoliberals were skeptical of the older vocabulary of "nature" and "artifice" (e.g. Hayek 1973, 20), this may have been less a substantive than a merely semantic change. 15 In a sense, the very contrast between "grown" and "made" order preserves the nature/artifice distinction in a different guise.

Such historical caveats aside, let's draw out the logic of this account of economic order. We've seen the centrality of the notion of general rules in theories of spontaneous order: we're free to act spontaneously insofar as we're subject only to universal laws rather than particular commands. In The Constitution of Liberty, Hayek had analogized properly general human laws to laws of nature. In later works, he would emphasize a different analogy: general rules as rules of the game. ${ }^{16}$

The metaphor's implications are worth unpacking. Rules of the game, Hayek writes, "guid[e] the actions of individual participants whose aims, skills, and knowledge are different, with the consequence that the outcome will be unpredictable and that there will regularly be winners and losers" $(1976,71)$. A game of the requisite type combines unpredictability with orderliness: we can't know in advance what will happen, but we can clearly tell which moves are permissible while the game is going on, and determine who won at the end.

Whether the rules can achieve these desiderata doesn't depend on any particular story about their origins. The origins of some games are shrouded in obscurity, and might be thought the result of a gradual process of evolution; others were the products of discrete moments of conscious design. Yet these disparate origins have no implications whatsoever for the games' abilities to furnish both order and unpredictability. Basketball was invented at a stroke by James Nai-

\footnotetext{
${ }^{14}$ Some neoliberals rhetorically distanced themselves from the term "laissez-faire" while insisting that it didn't accurately describe its usual referent, nineteenth-century British liberalism (Jackson 2010, 135). Wilhelm Röpke, for one, cast himself as modernizing laissez-faire rather than repudiating it: "Laissez-faire-yes, but within a framework laid down by a permanent and clear-sighted market police in the widest sense of this word" $(1942,228)$. No Physiocrat would have disagreed.

15 For instance, when examining Louis Rougier's introductory remarks at the Walter Lippmann Colloquium-the 1938 gathering often considered the seedbed of neoliberalism-Foucault was inclined to dismiss Rougier's references to a "spontaneous natural order" as an anachronism inconsistent with the main thrust of neoliberal thought (2008, 161-62). Yet the fact that Rougier's remarks can be rendered entirely consistent with Hayek by striking out the offending word "natural" suggests that the difference is not so fundamental.

16 The game metaphor would become widespread in twentieth-century social thought. Propounded between the wars by the Chicago economist Frank Knight, it was particularly important for John Rawls as well as Hayek (Forrester 2019, 12-14).
} 
smith in 1891, but this doesn't make the proceedings of a given basketball game any less of an exercise in orderly unpredictability.

Just as the game metaphor has little interest in origins, likewise it has little interest in motives or psychology. The question of why the players play, whether they want to play, is irrelevant; we simply assume that they want to win, and that their motives once the proverbial whistle blows are adequately specified by the rules themselves. In this sense, Hayek's suggestion that the players differ in their "aims" as well as their skills and knowledge is not quite right: if the players' aims differ too much, the game can no longer produce winners and losers. A basketball game only works if both teams agree that the aim is to score the most points (and not, say, to commit the most fouls).

The game metaphor has an intuitive appeal, and it dovetails with the emphasis on the active construction of order that we've been tracing. But it sits uneasily with other central elements of spontaneous order theory-for instance, the doctrine of perversity, with its suggestion that individuals are not infinitely conformable to any set of rules of the game, that they have some underlying moral psychology that will harmonize with certain constructions and resist others. 17 Hayek attributes the conception of social order as a game to Adam Smith, whose "man of system" passage - mentioned earlier as the locus classicus of the perversity doctrine-does indeed speak of "the game of human society." But Smith in that passage highlights the ways that social order differs from a normal game: "pieces upon the chessboard have no principle of motion besides that which the hand impresses upon them; but...in the great chessboard of human society, every single piece has a principle of motion of its own" (Smith 1976b, 234). The game metaphor suggests an open-ended view about the possibilities of construction: we can play an infinite number of games according to an infinite number of sets of rules, ready in turn to kick a ball, flip a card, sing a song as the rules demand. But spontaneous order theory has always emphasized the limits of rational construction. It must therefore assume some underlying view of human propensities, propensities which can be encouraged or thwarted by different sets of rules but which are not themselves stipulated by the rules.

\footnotetext{
17 This is especially true for Hayek, whose turn from mainstream economics toward spontaneous order theory was intertwined with his work in cognitive psychology (chiefly Hayek 1952).
} 
Nor can a reliance on general rules do the work that Hayek expects of it; in particular, it need not entail a liberal economic order. For one thing, the very notion of a general rule is blurry. While there are certain acts that clearly don't qualify as general rules (such as bills of attainder that explicitly target named individuals), it's quite easy to write rules that are formally general while functionally specific in their targets. ${ }^{18}$ Hayek is aware of this difficulty, and concedes that "in spite of many ingenious attempts to solve this problem, no entirely satisfactory criterion has been found" $(1960,209)$. Yet the problem goes beyond conceptual definitions, as many of Hayek's critics pointed out (e.g. Aron 1961): the ideal of the rule of law is more politically openended than he would allow, for there is no reason that a despotic regulation of social life couldn't be formulated entirely in terms of general rules.

This doesn't mean that the view sketched here-of order stemming from the conscious construction of general rules - is incoherent on its own terms. My claim is simply that if we adopt such a view wholesale, what we have is no longer recognizable as a theory of spontaneous order, but has become something else, closer to the "constructivist rationalism" that the theory has always opposed.

Perhaps this explains why spontaneous order theorists have never been entirely willing to abandon the backward-looking side of the theory, to dispense with origin stories and focus only on the construction of frameworks for the future. Hayek refers to spontaneous order and cultural evolution as "twin ideas" $(1978,250)$, and the claim has puzzled many of his interpreters, who rightly question whether an account of presently-existing order entails an evolutionary account of its origins (Barry 1982, 35; Gray 1988, 57-58; Petsoulas 2001, 32-33). Yet we can see reasons for this combination - for a spontaneity cut off from history, awaiting the conscious intervention of a lawgiver to display itself, would no longer seem to have much claim to spontaneity at all. Even the ordoliberals, more willing than Hayek to bite the bullet and embrace a vision of order as consciously constructed, still showed traces of a historical story much like his, in which it is only the twentieth-century disruption of what had previously been a grown order that makes its active re-

\footnotetext{
18 To pick an obvious contemporary example, a ban on headwear in public places might apply universally to all citizens while functionally targeting religious minorities.
} 
construction in the present necessary. ${ }^{19}$ None of the purely forward-looking accounts of spontaneous order that we've considered has proven fully adequate to the broader purposes of the theory. And this suggests that it might be not able to do without historical roots, that it must remain wedded to some claim that its favored order arose through some process that could plausibly be called spontaneous. With this thought in mind, we turn to Hayek's account of cultural evolution.

\section{Evolution}

Evolution by natural selection dispenses with teleology: it describes an undirected process in which the later stages are not meant to follow the earlier stages in any meaningful sense. Evolutionary theories can easily become moralized, suggesting that what comes later is superior to what comes earlier, but this is an error; properly understood, there is no suggestion that change is for the better (or for the worse). Much of the scholarly debate around Hayek's theory of cultural evolution has centered on whether he avoided this error, or whether he took the results of the process to be ipso facto good or valuable..$^{20}$

But evolution is also neutral in a different sense, of more concern to us here. Like the doctrine of unintended consequences, evolution by natural selection implies nothing about the motives or the cognition of the units that are subject to it. There is no escape from the process, which continues to occur regardless of whether we are aware of it and whether we act on this awareness. If we imagine an analogous form of selection occurring to social practices as well as organisms (not an uncontroversial assumption, of course), the implication would be that there's no possibility of "outside interference" with the process of cultural evolution. Humans act with varying degrees of reflection, planning, and willfulness, and in doing so they create various practices and institutions, some of which prove more successful than others and become widespread. The spread of a certain practice might lead to one set of unintended consequences, which gives rise to conscious attempts at adaptation and change, which in turn lead to a new set of unintended

\footnotetext{
19 E.g. Franz Böhm's suggestion that “there is no longer any space for a silent growth, for an orderly formation of things...from the bottom up" (quoted in Slobodian 2018, 211, my emphasis).

20 On Hayek's evolutionary theory more broadly, see Beck 2018.
} 
consequences, and so on. But there is no form of social action, from the most unreflective to the most ambitious, that we could describe as taking place outside this process.

Yet this is not how Hayek envisions cultural evolution. What gives his theory its distinctive slant, in fact, is his insistence on the non-cognitive and unwillful character of participants in the evolutionary process. Recall the doctrine of fecundity, with its suggestion that human beings are never more creative than when they renounce the urge to consciously create. In Hayek's historical account, this doctrine becomes something like a factual claim about how human society did in fact evolve, as he insists on the primacy of action rather than thought, habit rather than curiosity, tacit rather than explicit knowledge, rule-following rather than rule-making: "Man acted before he thought and did not understand before he acted." People habitually followed rules whose purposes they did not understand (and made no attempt to understand), and those practices which proved successful spread, "often not because they conferred any recognizable benefit on the acting individual but because they increased the chances of survival of the group to which he belonged." Rules of conduct "come to be observed because in fact they give the group in which they are practiced superior strength, and not because this effect is known to those who are guided by them" $(1973,18-19)$. And although Hayek goes some way in qualifying his statements - people didn't understand before they acted, practices often developed without their benefits being recognized - he provides no discussion of cases in which humans might arrive at some understanding of their practices, even if only retrospective. He associates such attempts at social knowledge with would-be designers "outside" the evolutionary process, whose efforts have the potential to interfere with it; actors "inside" the process are contentedly ignorant, apparently not even trying to discern the broader meaning of the rules they follow.

Individuals who follow a rule of conduct, on this account, will have little understanding of the social function that it serves; still less is such an understanding the reason why they follow it. Because they're unable to grasp the functions and benefits of their social practices, there's no clear reason why any of them would ever consciously exchange one rule or practice for another. And because, on these premises, it becomes difficult to see why an individual would ever adopt a new rule, the only mechanism that remains to explain the emergence and spread of such practices is blind selection. This dovetails with Hayek's assimilation of human and non-human sponta- 
neous orders, for he sees the distinctive attributes of the human elements that make up a social order as playing virtually no role in its operation. In both natural and social orders, we can attribute purpose to the individual elements only in the functional sense "that their actions tend to secure the preservation or restoration of that order," but this doesn't imply any subjective "awareness of purpose" on the part of the elements themselves $(1973,39)$.

Is it really conceivable that any human beings could be so incurious, so unambitious, as Hayek requires them to be? Part of the problem is that he suggests a stark binary of habitual rulefollowing and constructivist rationalism, as if the only alternative to blind non-cognitive reaction were a kind of syllogistic deduction from explicit rational premises. There are many excluded possibilities here, and they contain a great deal of the social action of the actual world: willing, striving, experimenting, scheming, guessing, pretending, and so on. Hayek has been accused of downplaying the role of reason in the process of cultural evolution (e.g. Barry 1982, Petsoulas 2001). But reason is only one of the capacities that he downplays, and perhaps not the most important. The problem is first and foremost a descriptive rather than normative one: not so much that he neglects the possibility of rationally reconstructing the social world in better ways, but that he ignores capacities (both good and bad, rational and non-rational) which must have been central to any actual processes of historical development.

Hayek's sketch of the development of law is a striking illustration of these difficulties. Lawmaking might be considered the central counterexample to his view of cultural evolution, the moment when humans can't simply follow an inherited rule but must make the rules themselves. We've seen that Hayek occasionally flirted with the notion that the rules of a spontaneous order might themselves be consciously designed. But we've equally seen his reasons for shying away from it, and suggesting that the rules themselves must arise spontaneously. When dealing with the undeniable fact of legislation throughout history, Hayek must therefore seek to minimize the willful and creative aspect of the process as much as possible. "[L]aw existed for ages before it occurred to man that he could make or alter it," he suggests, and "all early 'law-giving' consisted in efforts to record and make known a law that was conceived as unalterably given." In this process "nobody had the power or the intention to change the law," and thus "the changes which did occur were not the result of intention or design of a law-maker" $(1973,73,81)$. 
As we move forward in history, judges take the place of lawgiving rulers as the protagonists of Hayek's story. It is the English common-law judge, in particular, who serves as his model for the kind of lawmaking that is consistent with grown order, based on a reactive and conservative mentality that aims only to preserve the existing equilibrium. Of course, in a dynamic situation, preservation requires change, and the judge is forced in practice to create new law to maintain the old order. But Hayek stresses that "even when in the performance of this function he creates new rules, he is not a creator of a new order but a servant endeavoring to maintain and improve the functioning of an existing order." New law is indeed made in such system, but without any conscious design to do so, for the "task will be regarded as one of discovering something which exists, not as one of creating something new" $(1973,119,78)$.

Are these normative ideals for how the law should operate, or historical descriptions of how it did? For a backward-looking theory of spontaneous order to work, they must to some significant extent be the latter; without claiming that law everywhere and always evolved on this model, the theory needs some claim to historicity. And yet here Hayek's account looks rather credulous, as the political dimension of lawmaking drops out of the picture entirely. It may (or may not) be true, for instance, that ancient lawgivers conceived of their task as bringing human law into accordance with an immutable divine law, but it hardly follows that they had neither "the power or the intention" to alter existing human law, or any broader goals in doing so. Likewise, Hayek's sketch of the English common-law judge essentially restates the stylized depictions offered by jurists like Edward Coke and Matthew Hale in the course of seventeenth-century polemics against absolutism. They aimed to show that the common law had developed organically, independent of the central sovereign, but historians from Maitland onward have shown how misleading such a picture is (cf. Hamowy 2003). Above all, what's absent from Hayek's sketch is a sense of the connection between law and power, the capacity of law to serve as an instrument by which people pursue their own aims. Because he views genuine law (as opposed to particular commands) as general and therefore politically neutral, he can only view power as an infringement upon the process of lawmaking rather than a constitutive part of it. ${ }^{21}$

\footnotetext{
${ }^{21}$ Hayek mentions in passing the existence of forms of legal discrimination which resulted from "the greater influence that certain groups...had wielded on the formation of the law" $(1973,141)$, but sees such instances as the exception rather than the rule.
} 
The example of law illustrates a broader point about Hayek's historical account. He frames it as a counter to the errors of constructivist rationalism, and on this level it perhaps succeeds too easily: there's little reason to deny that historical institutions tend to result from an interplay of many wills, and an accretion of unintended consequences, rather than from the implementation of a single top-down design. But Hayek's history requires premises that are much stronger, and ultimately quite implausible. It demands that we strip social actors not just of rationalism (in some grand Enlightenment sense) but of any politically salient form of will, desire, or ambition. Actors inside the evolutionary process might pursue their immediate interests within the rules, and even exercise a certain amount of planning and ingenuity in doing so; what they can't do is willfully aim at changing the rules, for then they would become intruders from outside the process. Only a world populated by such unambitious actors can produce institutions that are spontaneous in the sense Hayek envisions, and it's hard to see when in history such a world has ever existed.

Where, in such a world, does novelty come from? If human action is governed entirely by habit, adaptation, and rule-following, how does anything ever happen? In a sense, this was a critique that Nietzsche had already leveled against the social evolutionism of his own day (particularly that of Herbert Spencer). Nietzsche's genealogy shares some common features with these evolutionary theories, notably in their denial of teleology and the centrality they attach to struggle. But he complains that such theories place "'adaptation' in the foreground, that it to say, an activity of the second rank, a mere reactivity," meaning that "one overlooks the essential priority of the spontaneous, aggressive, expansive, form-giving forces that give new interpretations and directions, although 'adaptation' follows only after this" $(1989,79) .{ }^{22}$ Without taking on board all of Nietzsche's own philosophical baggage, we might agree that any account of social order needs some source of novelty and creativity, not just unthinking adaptation to the way things are done.

Indeed, Hayek sometimes accepts that spontaneous order requires rule-breakers as well as rule-followers. Progress depends on innovation, so that it is "often desirable that rules should be

\footnotetext{
22 Note the appearance here of our "strange word," spontaneous (spontan in German), attached to a set of traits that are precisely the opposite of the ones Hayek valorizes - yet another indication of how slippery the term is.
} 
observed only in most instances and that the individual should be able to transgress them when it seems to him worthwhile to incur the odium which this will cause" (1960, 63). "Most of these steps in the evolution of culture," he writes elsewhere, "were made possible by some individual breaking some traditional rules and practicing new forms of conduct" $(1979,161)$. Yet he can only accommodate the existence of such rule-breakers by drastically constricting their range of action - for the rule-breakers he has in mind are not the rebel, the prophet, or the conqueror, but the merchant, the inventor, and the entrepreneur. Thus he identifies the violation of customs with the "evolution of individual freedom," as some trailblazers broke free of older communitarian norms to barter with outsiders, establish private property, enforce contracts, lend at interest, and so on $(1979,161)$. But why couldn't they also have pursued their interests through force and fraud, coercion and manipulation? Far from civilization being solely "made possible by the delimitation of protected domains of individuals or groups" $(1973,108)$, doesn't the historical record indicate that it has equally been enabled by expropriation, conquest, and enslavement?

Hayek's emphases are, of course, perfectly understandable as normative preferences; the point is not to denounce a preference for trade over pillage, or for merchants over conquerors. The point is rather to question whether a purportedly historical account of social evolution can enshrine these preferences as matters of fact. Any number of human capacities, attractive and ugly, have been on display through history; by what criterion do we label some of them spontaneous and others not? Hayek does not so much argue against his disfavored capacities as write them out of history altogether. Nietzsche's "aggressive, expansive" tendencies become identified solely with post-Enlightenment rationalists aiming to impose their designs upon society; what comes before are rule-followers and a tamed sort of rule-breaker, one already bounded by the rules of the market. ${ }^{23}$ Anything that does not conform to this picture is cast as an outside infringement upon the evolutionary process rather than a constituent part of it; only in this way can the modern market order appear as a spontaneous outgrowth of human nature.

No doubt some of these problems are peculiar to Hayek's own theory. But I've dwelled on them because I suspect that any attempt at a backward-looking theory of spontaneous order is

\footnotetext{
23 Cf. Hayek's comparison of his own narrative to the story of the Fall $(1964,7 \mathrm{n} 10)$ : “There thus seems to be some truth in the alleged original state of goodness in which everybody spontaneously did right and could not do otherwise, and to the idea that only with increased knowledge came wrongdoing... without such knowledge, no sin."
} 
likely to run into analogous problems. Spontaneity is a concept that implies an outside-some form of action or some form of order that is non-spontaneous. (In this sense, the notion will always rest on some version of the natural/artificial dichotomy, however much we might disavow that language.) A forward-looking theory deals with this analytically, by defining as spontaneous the results of any system with certain characteristics (whatever its origins might be). A backward-looking theory must instead venture a claim about which human capacities are truly spontaneous, and provide a historical story showing that its favored institutions did indeed arise through the exercise of these capacities and no others. And this is an enterprise that is always likely to end in a fairy tale.

This is not to deny, however, that spontaneous order theory contains some genuine insights about history, above all concerning the limits of rationalism and the importance of unintended consequences. What would a backward-looking view built on these insights look like that discarded the untenable parts of the theory? I suggest that we can trace various versions of such a view among the thinkers whom spontaneous order theorists claim as their progenitors, the philosophers of the Scottish Enlightenment.

\section{History}

“[T]here followed from this revolution many beneficial consequences," David Hume writes at one point in his History of England, "though perhaps neither foreseen nor intended by the persons who had the chief hand in conducting it" (1983, III:207). We have what looks like a classic example of the doctrine of fecundity, in which the actions of short-sighted individuals unwittingly lead to collective benefits. Look closer, though, and the example becomes less straightforward. The "revolution" that Hume describes is Henry VIII's wholesale expropriation of the Catholic Church, which surely qualifies as one of the most sweeping projects of top-down social engineering in European history. Hume does not downplay "the violence of changing so suddenly the whole system of government," but nonetheless insists that its effects were ultimately beneficial (1983, III:220). And these sorts of paradoxes appear frequently in his history. Parliament's seventeenth-century encroachments upon royal power were "rash and adventurous," he writes, yet their eventual "advantages....should render the English grateful to the memory of 
their ancestors" (1983, V:329; see also Sabl 2002). Likewise, religious toleration didn't initially spring from any sort of spirit of moderation, but rather from the fanatical "enthusiasm" of revolutionary Protestant sectarians (Conti 2015).

Such examples don't imply that Hume was advocating violent revolution or millenarian religiosity. On the contrary, he was what he is generally thought to be, an advocate of gradual reform. His point was simply that unforeseen consequences were, on some basic level, genuinely unforeseeable. When planning in the present, he thought, we must assume that meliorist change is likely to be healthy and violent innovation to be self-defeating; looking backward, we must recognize that oftentimes the reverse was true. Humility didn't always pay, and pride wasn't always punished, but no one could've known in advance when this would be true.

The paradoxical quality of Hume's history has an echo in his social theory. He is rightly known for his analysis of conventions: forms of coordination based on common knowledge, in which "the actions of each of us have reference to those of the other," yet without any explicit promise or agreement being made $(1978,490) .{ }^{24}$ And he pointed to the ways in which political life itself is conventional, for it is ultimately "on opinion only that government is founded" $(1987,32)$. But whether a given practice operates conventionally in the present is distinct from whether it originated through bottom-up accommodation or top-down imposition, and answers will differ depending on the convention. For instance, any political regime's stability in the present depends on convention, as obedience "becomes so familiar, that most men never make any enquiry about its origin or cause"- but if we do delve into a given regime's origins, we will discover that invariably it arose from "usurpation or conquest" $(1987,470-71)$. The frequent disjuncture between historical origins and present-day operations explains some of the untidiness of Hume's own history, its irony, and its resistance to readily universalizable lessons. It wasn't a typical Whig history in more ways than one.

This untidiness is equally characteristic of other Scottish Enlightenment thinkers. Hayek was fond of quoting the line from Adam Ferguson's Essay on the History of Civil Society that "nations stumble upon establishments, which are indeed the result of human action, but not the execution of any human design." But the passage in which the line appears drives home the dis-

24 Notable analyses of this Humean theme include Lewis 1969, Sugden 1989, Hardin 2007, Sabl 2012, Sagar 2018. 
tance between the two. For Ferguson, unintended consequences are pervasive not because humans are governed by habit, tradition, or immediate interest, but because they are so inclined to form grand designs; it's precisely because everyone is so prone "to occupy themselves in forming projects and schemes" that so few schemes end up proceeding as planned $(1995,119)$. Ferguson's vision of history is tumultuous, with unintended benefits occurring in the moments when such ambitions check one another, and with freedom itself appearing as a consequence of this struggle rather than a precondition of it, being "maintained by the continued differences and oppositions of numbers" rather than by consensus or concord $(1995,124-25)$. This vision has been passed down to us in its defanged form, as the individual pursuit of self-interest sufficiently constrained by a shared respect for the underlying rules of the game. Ferguson imagined it in terms closer to Machiavelli's: a competition for power and glory as well as wealth, waged between classes as well as individuals, with no assurance that the parties would respect any particular set of ground rules and no guarantee that their struggle would ultimately make them better off. ${ }^{25}$

Adam Smith might be the most striking case. Smith's depiction of the invisible hand in commercial society is widely taken as the canonical instance of spontaneous order. Yet Smith did not think that European commercial society itself was a spontaneous formation: on the contrary, in its imbalance toward manufacturing over agriculture and the city over the country, it represented an "unnatural and retrograde" inversion of the "natural order of things" (1976a, 380; and see Hont 2005, 354-88). This was no defect, however, for "nature" had little to recommend it. Humans were naturally inclined not towards exchange and material betterment, but towards domination and violence: although "management and persuasion are always the easiest and the safest instruments," while "force and violence are the worst and the most dangerous," the "natural insolence of man" meant that "he almost always disdains to use the good instrument, except when he cannot or dare not use the bad one" (1976a, 799). And if commercial society represented an "unnatural and retrograde" aberration, it was a fortunate one, for the innate human libido dominandi meant that the most natural (we might say "spontaneous") path of social development consisted of progressively harsher slave societies (Luban 2012).

\footnotetext{
25 This chapter of Ferguson's Essay (telling titled "The History of Subordination") contains many echoes of Machiavelli's Discourses, particularly the discussion of how class conflict in Rome, the "disunion" of the plebs and senate, "made that republic free and powerful" (Machiavelli 1996, 16).
} 
Without purporting to offer a comprehensive view of any of these thinkers, such examples help indicate where they diverge from later spontaneous order theorists. ${ }^{26}$ The apparent resemblance rests mainly on how central some notion of unintended consequences is to all of them. Yet we've seen that spontaneous order theory requires stronger premises, notably the twin doctrines of fecundity and perversity, which impose a form of predictability on the raw unpredictability implied by the idea of unintended consequences on its own. And it is this predictability that the Scottish Enlightenment thinkers denied. Their vision of human beings recognized the ubiquity of those capacities — the urges to scheme, interfere, dominate, and so on — whose absence spontaneous order presupposes. Accordingly, their vision of history emphasized the genuine unpredictability of human social life, and the paradoxes by which these unappealing human capacities might sometimes result in collective benefit. 27

What separates these eighteenth-century thinkers from later spontaneous order theory is more than just a difference in intellectual temperament; it also stems from a difference in historical horizons. Spontaneous order theory grew out of twentieth-century anticommunism, and the fight against state encroachment upon economic life more broadly. The dichotomy of state and market underlies the entire theory in ways that are far-reaching yet rarely made explicit - the market as bearer of spontaneity, the state as bearer of constructivist rationalism; the market as realm of peaceful competition, the state as realm of coercive force; the market as grown, the state as making and made. Spontaneous order is a concept that requires an "outside," a location from which the threat of interference might come, and this might seem a perplexing idea: how could any social actor be external to what Hayek calls "the order of the whole of society"? If we wish, as Hayek does, to reject the errors of "Cartesian dualism," with its understanding of "an independently existing mind substance" that designs the world from outside $(1973,17)$, shouldn't we conclude that outside interference with the social world is not just undesirable but actually im-

\footnotetext{
26 Hayek frequently cast himself as an heir to the Scottish Enlightenment, and scholars have generally followed him in this (e.g. Barry 1982, Hamowy 1987, D’Amico 2015). For works that distinguish Hayek from his predecessors along rather different lines than I do here, see Gray 1988, Petsoulas 2001, Whyte 2019.

27 We sometimes soften the edges of this vision by imagining that these thinkers believed in an overarching providence that inevitably transmuted bad into good. But providence in the eighteenth century was a loose notion, and one that didn't always bear a great deal of argumentative weight. Far from offering definitive reconciliation, invocations of providence could equally represent a confession of perplexity, a kind of analytical shrug of the shoulders.
} 
possible? Yet spontaneous order theory from Hayek onward has operated on the implicit assumption that the state does indeed stand "outside the system," so that it's capable of acting "exogenously" toward the endogenous order of the market $(1973,36)$. And all the capacities written out of the rest of the story—scheming, ambition, domination— - get attached exclusively to the state and its agents.

Spontaneous order theory, in other words, presupposes differentiation: a political sphere, in which a centralized sovereign state wields a monopoly of coercive force, and an economic sphere, a decentralized market whose participants must rely on non-coercive means. ${ }^{28}$ Yet historically, as Norbert Elias reminds us, "[n]othing is less self-evident” than such a division (2000, 303). The norm is rather for these spheres to be intimately intertwined if not identical, with relations of production and distribution shading into relations of rule and obedience, and profit motives shading into power motives.

For the Scottish Enlightenment thinkers, this intertwining had characterized the relatively recent European past, the feudal world from which European commercial society had arisen. What they tried to understand, in their various individual ways, was how this had happened: how feudalism had given way to a world in which state and market became recognizable as distinct entities. ${ }^{29}$ The differentiation of politics and economics, far from being a guiding assumption, was the thing that had to be explained. And such an explanation couldn't be a simple story of the liberation of the inside from the outside, of the market from the state, for this would presuppose categories which had not yet come into being. Nor could it ignore the ubiquity of those capacities that spontaneous order theory tends to exile to the outside, to quarantine in the modern state. It was true that the modern world hadn't sprung from the plan of any designing intelligence — but it was equally true that its emergence didn't appear in any meaningful way spontaneous or natural. This was the puzzle with which the eighteenth-century historians of civil society began. Without claiming that they successfully solved this puzzle, recognizing its existence helps explain why

\footnotetext{
28 I leave aside the question of whether modern societies have indeed become differentiated in this way, or whether the distinction between political and economic spheres is simply an analytical assumption (and potentially a misleading one).

${ }^{29}$ For this reading of Adam Smith, see Luban 2012. On this genre of eighteenth-century historiography more generally, see Pocock 1999.
} 
they emphasized paradox, antagonism, and unpredictability in ways that their twentieth-century successors would only claim to do.

\section{Possibilities}

Spontaneous order is an alluring idea for several reasons. It claims to explain social complexity from modest premises, accounting for collective outcomes with minimal reference to individual intentions. It promises to do so in a way that will integrate the social sciences with the natural sciences. It offers a political message of humility, deflating the pretensions of overambitious planners and calling for the protection of grown order. Perhaps most importantly - and contrary to the frequent suggestion that the theory's message is one of alienation and doubt-it provides a form of reconciliation to members of large impersonal societies. The note of warning directed against the encroaching state comes with a note of reassurance directed at everyone else: by minding our business and doing our modest part, we unwittingly contribute to something greater than ourselves.

The challenge is to give some content to the elusive notion of spontaneity that will allow the theory to fulfill these various promises. We've traced various possibilities for meeting this challenge, but in each case spontaneous order threatens to tip over into something else. It can be a minimal and amoral theory of unintended social regularities in general, but only by extending the notion of order much farther than its practical purposes would allow. It can be a formal account of hierarchy and its absence, but only at the cost of substituting legalism for social theory. It can be a vision of consciously constructed rules, but only by edging dangerously close to the constructivist rationalism that it wishes to oppose. It can be a Whig history of the evolution of freedom, but only by projecting a form of modern market socialization back across history. It can double down on its stated premise of unpredictability, but only by forsaking its tacit claim to predictability.

Perhaps some new version of the theory will be able to avoid these pitfalls. But I am inclined to doubt that spontaneity will ever be able to bear the weight that is required of it. This conclusion wouldn't require us to abandon every individual insight proposed by Hayek and his 
interlocutors. But it would require us to detach their political vision from the untenable claim to spontaneity, instead understanding this vision as simply one - among many-possible orders.

ACKNOWLEDGEMENTS: I thank audiences at Yale, the University of Virginia, and the APSA annual meeting in Washington for the chance to present early versions of some of this material, and I especially thank discussants Alex Bleiberg, Stefan Eich, Andrew Sabl, and Daniel Steinmetz-Jenkins for their helpful comments. For further discussion of these themes and other help along the way, I am grateful to Gary Herrigel, Ben Jackson, Karuna Mantena, John McCormick, Sankar Muthu, Jennifer Pitts, Sophie Smith, and Kenta Tsuda. Finally, I thank Leigh Jenco and the APSR editorial team along with four anonymous reviewers for their guidance. 
References

Aron, Raymond. 1961. "La définition libérale de la liberté." Archives européennes de sociologie 2: $199-218$.

Augustine. 1998 [413-26]. The City of God Against the Pagans. Trans. R.W. Dyson. Cambridge: Cambridge University Press.

Barry, Norman. 1982. “The Tradition of Spontaneous Order.” Literature of Liberty 5(2): 7-58.

Beck, Naomi. 2018. Hayek and the Evolution of Capitalism. Chicago: University of Chicago Press.

Bourdeau, Michel. 2016. “Fallait-il oublier Comte?” Revue européenne des sciences sociales 54(2): 89-111.

Caldwell, Bruce. 2004. Hayek’s Challenge. Chicago: University of Chicago Press.

Conti, Greg. 2015. "Hume’s Low Road to Toleration.” History of Political Thought 36: 165-91.

Dale, Gareth. 2018. “Our World Was Made by Nature.” Globalizations 15: 924-40.

D’Amico, Daniel J. 2015. “Spontaneous Order.” In The Oxford Handbook of Austrian Economics, ed. Peter J. Boettke and Christopher J. Coyne. Oxford: Oxford University Press, 115-42.

de Maistre, Joseph. 1974 [1795]. Considerations on France. Trans. Richard Lebrun. Montreal: McGill University Press.

Elias, Norbert. 2000 [1939]. The Civilizing Process. Trans. Edmund Jephcott. Oxford: Blackwell.

Elster, Jon. 1989. The Cement of Society. Cambridge: Cambridge University Press.

Ferguson, Adam. 1995 [1767]. An Essay on the History of Civil Society. Ed. Fania Oz-Salzberger. Cambridge: Cambridge University Press.

Forrester, Katrina. 2019. In the Shadow of Justice. Princeton: Princeton University Press.

Foucault, Michel. 2008. The Birth of Biopolitics. Trans. Graham Burchell. Basingstoke: Palgrave Macmillan.

Gamble, Andrew. 1996. Hayek. Cambridge: Cambridge University Press.

Gray, John. 1984. Hayek on Liberty. Oxford: Blackwell.

Gray, John. 1988. "Hayek, the Scottish School, and Contemporary Economics." In The Boundaries of Economics, ed. Gordon C. Winston and Richard F. Teichgraeber III. Cambridge: Cambridge University Press, 53-70.

Hamowy, Ronald. 1987. The Scottish Enlightenment and the Theory of Spontaneous Order. Carbondale: Southern Illinois University Press.

Hamowy, Ronald. 2003. "F.A. Hayek and the Common Law.” Cato Journal 32: 241-64.

Hardin, Russell. 2007. David Hume. Oxford: Oxford University Press.

Hayek, F.A. 1948. Individualism and Economic Order. Chicago: University of Chicago Press.

Hayek, F.A. 1952. The Sensory Order. Chicago: University of Chicago Press.

Hayek, F.A. 1960. The Constitution of Liberty. London: Routledge \& Kegan Paul.

Hayek, F.A. 1964. “Kinds of Order in Society.” New Individualist Review 3(2): 3-12. 
Hayek, F.A. 1973. Law, Legislation and Liberty, Vol. 1: Rules and Order. Chicago: University of Chicago Press.

Hayek, F.A. 1976. Law, Legislation and Liberty, Vol. 2: The Mirage of Social Justice. Chicago: University of Chicago Press.

Hayek, F.A. 1978. New Studies in Philosophy, Politics, Economics and the History of Ideas. Chicago: University of Chicago Press.

Hayek, F.A. 1979. Law, Legislation and Liberty, Vol. 3: The Political Order of a Free People. Chicago: University of Chicago Press.

Hobbes, Thomas. 1841 [1656]. The Questions Concerning Liberty, Necessity, and Chance. Vol. 5 of The English Works of Thomas Hobbes of Malmesbury, ed. William Molesworth. London: Bohm.

Hirschman, Albert O. 1991. The Rhetoric of Reaction. Cambridge: Belknap Press.

Hont, Istvan. 2005. Jealousy of Trade. Cambridge: Belknap Press.

Hume, David. 1978 [1739]. A Treatise of Human Nature. Ed. L.A. Selby-Bigge and P.H. Nidditch. Oxford: Oxford University Press.

Hume, David. 1983 [1754-61]. The History of England. 6 vols. Indianapolis: Liberty Fund.

Hume, David. 1987 [1758]. Essays, Moral, Political, and Literary. Ed. Eugene F. Miller. Indianapolis: Liberty Fund.

Jackson, Ben. 2010. “At the Origins of Neo-Liberalism.” The Historical Journal 53: 129-51.

Kalyvas, Stathis N. 2006. The Logic of Violence in Civil War. Cambridge: Cambridge University Press.

Kley, Roland. 1994. Hayek's Social and Political Thought. Oxford: Clarendon Press.

Kukathas, Chandran. 1989. Hayek and Modern Liberalism. Oxford: Clarendon Press.

Lewis, David. 1969. Convention. Cambridge: Harvard University Press.

Luban, Daniel. 2012. “Adam Smith on Vanity, Domination, and History.” Modern Intellectual History 9: 275-302.

Luban, Daniel. 2017. “The Elusive Karl Polanyi.” Dissent 64(2): 68-78.

Luban, Daniel. 2018. "Coercive in a Subjective World.” Working paper.

Machiavelli, Niccolò. 1996 [1531]. Discourses on Livy. Trans. Harvey C. Mansfield and Nathan Tarcov. Chicago: University of Chicago Press.

Merton, Robert K. 1936. "The Unanticipated Consequences of Purposive Social Action." American Sociological Review 1: 894-904.

Mirowski, Philip. 2018. “Polanyi vs Hayek?” Globalizations 15: 894-910.

Nietzsche, Friedrich. 1989 [1887]. On the Genealogy of Morals and Ecce Homo. Trans. Walter Kaufmann. New York: Vintage.

Parsons, Talcott. 1968 [1937]. The Structure of Social Action. 2 vols. New York: Free Press.

Petsoulas, Christina. 2001. Hayek's Liberalism and its Origins. Abingdon: Routledge.

Piccione, Michel and Ariel Rubinstein. 2007. "Equilibrium in the Jungle." The Economic Journal 117: 883-896. 
Pocock, J.G.A. 1999. Barbarism and Religion, Vol. 2: Narratives of Civil Government. Cambridge: Cambridge University Press.

Polanyi, Karl. 2001 [1944]. The Great Transformation. Boston: Beacon Press.

Polanyi, Michael. 1941. "The Growth of Thought in Society.” Economica NS 8: 428-56.

Polanyi, Michael. 1951. The Logic of Liberty. London: Routledge \& Kegan Paul.

Radford, R.A. 1945. “The Economic Organization of a P.O.W. Camp.” Economica NS 12: 189-201.

Röpke, Wilhelm. 1942. The Social Crisis of Our Time. Chicago: University of Chicago Press.

Sabl, Andrew. 2002. "When Bad Things Happen From Good People (and Vice-Versa)." Polity 35: 73-92.

Sabl, Andrew. 2012. Hume's Politics. Princeton: Princeton University Press.

Sagar, Paul. 2018. The Opinion of Mankind. Princeton: Princeton University Press.

Sandefur, Timothy. 2009. "Some Problems with Spontaneous Order." The Independent Review 14: 5-25.

Sheehan, Jonathan and Dror Wahrman. 2015. Invisible Hands. Chicago: University of Chicago Press.

Slobodian, Quinn. 2018. Globalists. Cambridge: Harvard University Press.

Smith, Adam. 1976a [1776]. An Inquiry into the Nature and Causes of the Wealth of Nations. Ed. R.H. Campbell, A.S. Skinner, and W.B. Todd. 2 vols. Oxford: Clarendon Press.

Smith, Adam. 1976b [1759]. The Theory of Moral Sentiments. Ed. D.D. Raphael and A.L. Macfie. Oxford: Clarendon Press.

Stahl, Rune Møller. 2019. “Economic Liberalism and the State.” New Political Economy 24: 473-86.

Sugden, Robert. 1989. "Spontaneous Order.” The Journal of Economic Perspectives 3: 85-97.

Ullmann-Margalit, Edna. 1978. “Invisible-Hand Explanations.” Synthese 39: 263-91.

Vernon, Richard. 1979. “Unintended Consequences.” Political Theory 7: 57-73.

Whyte, Jessica. 2019. “The Invisible Hand of Friedrich Hayek.” Political Theory 47: 156-84. 